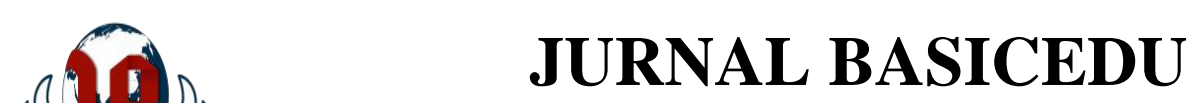

Volume 5 Nomor 4 Tahun 2021 Halaman 2521 - 2529

Research \& Learning in Elementary Education https://jbasic.org/index.php/basicedu

PAHLAWAN

\title{
Pengaruh Process Oriented Guided Inquiry Learning (POGIL) terhadap Kemampuan Berpikir Kritis Siswa di Sekolah Dasar
}

\author{
Setyani Wijaya ${ }^{1 凶}$, Sri Lestari Handayani ${ }^{2}$ \\ Pendidikan Guru Sekolah Dasar, Universitas Muhammadiyah Prof. Dr. Hamka, Indonesia ${ }^{1,2}$ \\ E-mail: setyaniw08@gmail.com ${ }^{1}$, srilestarih@uhamka.ac.id²
}

\begin{abstract}
Abstrak
Penelitian ini bertujuan untuk mengetahui pengaruh model pembelajaran Process Oriented Guided Inquiry Learning (POGIL) terhadap kemampuan berpikir kritis siswa pada materi kalor dan perpindahannya. Penelitian ini dilakukan di SD Angkasa 4 tahun ajaran 2020/2021 pada semester genap. Metode penelitian yang digunakan adalah quasi eksperimen dengan desain control group pre-test post-test. Populasi dalam penelitian ini sejumlah 81 siswa dan sampel untuk kelas eksperimen 26 siswa dan kelas kontrol 27 siswa. Teknik pengambilan sampel yang digunakan menggunakan random sampling. Dalam perhitungan dibantu dengan bantuan SPSS versi 26 for windows. Teknik analisis data uji hipotesis menggunakan uji-t Independent T-Tes dari pengolahan data didapatkan hasil sebesar Asymp.(2-tailed) $<\alpha=5 \%$ yaitu $0,010<0,05$ sehingga dapat diketahui bahwa $\mathrm{H}_{0}$ ditolak dan $\mathrm{H}_{1}$ diterima. Maka dapat disimpulkan bahwa model pembelajaran Process Oriented Guided Inquary Learning (POGIL) terdapat pengaruh positif dan signifikan terhadap kemampuan berpikir kritis siswa kelas V SD Angkasa 4 pada materi kalor dan perpindahannya.
\end{abstract}

Kata Kunci: kemampuan berpikir kritis, POGIL sekolah dasar, kalor dan perpindahannya.

\begin{abstract}
The purpose of this research the effect of thelearning model Process Oriented Guided Inquiry Learning (POGIL)on students' critical thinking skills on heat material and its displacement. This research was conducted at SD Angkasa 4 for the academic year 2020/2021 in the even semester. The research method used is quasi-experimental with adesign pre-test post-test control group. The population in this study was 81 students and the sample for the experimental class was 26 students and the control class was 27 students. The sampling technique used is using random sampling. In the calculations assisted with the help of SPSS version 26 for windows. Data analysis techniques hypothesis testing using t-test Independent T-test of the data processing results obtained by Asymp. (2-tailed) $<\alpha=5 \%$, ie 0,010 $<0.05$ so that it can be seen that $H_{o}$ rejected and $\mathrm{H}_{1}$ accepted. So it can be concluded that thelearning model Process Oriented Guided Inquary Learning (POGIL)has a positive and significant influence on the critical thinking skills of fifth graders at SD Angkasa 4 on heat and its displacement.
\end{abstract}

Keywords: critical thinking skill, POGIL, elementary school, heat and transfer.

Copyright (c) 2021 Setyani Wijaya, Sri Lestari Handayani

Corresponding author :

Email : setyaniw08@gmail.com

DOI : https://doi.org/10.31004/basicedu.v5i4.1227

ISSN 2580-3735 (Media Cetak)

ISSN 2580-1147 (Media Online)

Jurnal Basicedu Vol 5 No 4 Tahun 2021

p-ISSN 2580-3735 e-ISSN 2580-1147 
2522 Pengaruh Process Oriented Guided Inquiry Learning (POGIL) terhadap Kemampuan Berpikir Kritis Siswa di Sekolah Dasar - Setyani Wijaya, Sri Lestari Handayani

DOI: https://doi.org/10.31004/basicedu.v5i4.1227

\section{PENDAHULUAN}

Pemerintah terus menggalakan perkembangan dunia pendidikan, karena pendidikan adalah tolak ukur suatu bangsa apabila pendidikan suatu bangsa tinggi atau baik, maka bangsa tersebut dapat ditempatkan pada tataran pergaulan dunia yang bermatabat dan modern. Jika suatu bangsa memiliki pendidikan yang baik maka akan mencentak generasi emas yang diharapkan dapat berkompetitif secara baik tidak hanya di dalam negeri tetapi mampu secara global. Kita sekarang menghadapi era globalisasi, semua bidang dalam kehidupan seharihari mengalami perkembangan secara pesat. Dengan pesatnya perkembangan akan memunculkan berbagai masalah kehidupan yang akan dihadapi dan harus diselesaikan secara sistematis.

Pembelajaran abad ke-21 dihadapkan peserta didik dapat menuntaskan masalah yang dihadapai dengan berpikir ilmiah dan kritis. Dalam pelaksanaannya di sekolah, penerapan 4C sesuai dengan tujuan kurikulum 2013. Yang dimana dalam pelaksanaan proses belajar mengajar melibatkan untuk berkomunikasi, kemampuan berkolaborasi, berpikir kritis dan memecahkan masalah, dapat berpikir kreatif dan inovatif. Diharapkan dengan menerapkan 4C peserta didik dapat membawa perubahan bagi negara. (Pendidikan, 2016).

Berpikir kritis mempunyai peran yang sangat besar bagi siswa dalam abad 21. Pencapaian terbesar yang diterima Guru adanya perubahan kognitif, afektif dan psikomotorik bagi siswa, dikarenakan tujuan yang telah ditetapkan dapat terrelisasikan dengan baik. Untuk mencapai kesuksesan tersebut, siswa dapat mengembangkan berpikir kritis untuk mencari solusi dari masalah yang ditemui. Sulistyowarni (2019:3) memaparkan bahwa masing-masing peserta didik dapat membuat suatu keputusan yang besar dengan menerapkan kemampuan berpikir kritis.

Berpikir kritis yang dipaparkan oleh Ennis (1996:167) yaitu berpikir mempertimbangkan dan menilai data yang diperoleh secara logis dan reflektif dan pada akhirnya membuat peserta didik secara efektif mencapai keputusan. Hal ini sejalan dengan oleh Cross \& Angelo (1988:5) dalam mencapai suatu tujuan dibutuhkan kemampuan berpikir kritis melalui beberapa tahapan menguraikan masalah yang ada, merumuskan masalah, memecahkan masalah dengan berbagai informasi yang didapat dan mampu memberikan keputusan yang tepat dari informasi sesuai dengan konteks nyata.

Menurut Richard Paul dalam Possin, (2017:3) mengungkapkan pada dasarnya setiap manusia dapat mengatasi persoalan dengan menggunakan wawasan yang dimilikinya. Berpikir kritis yang dimiliki seseorang dapat mengkaji data atau informasi dengan memanfaatkan pemikiran yang logis. Pernyataan sependapat dengan Yasushi (2011:353) bahwa kemampuan individu untuk memecahkan masalah secara logis. Hal ini juga di ungkapkan oleh Kowiyah (2012:177) dengan permasalahan yang dapat dipecahkan secara sistematis maka seseorang mampu menyetujui berbagai pendapat, kesimpulan, serta mampu diterapkan dalam proses belajar mengajar. Keadaan tersebut juga selaras diungkapkan oleh Facione (2011) bahwa proses membuat keputusan yang berdasarkan pertimbangan berdasarkan sesuai dengan konteks nyata, situasi dan konsep dari permasalahan yang akan diselesaikan.

Dari pemaparan ahli diatas kemampuan berpikir kritis yaitu, kemampuan seseorang dengan mempertimbangkan dan menilai data secara logis, rekflektif, konteks nyata, situasi dan konsep dari permasalahan dengan menggunakan wawasan yang dimilikinya. Dengan melakukan beberapa tahapan yaitu, menguraikan masalah yang ada, merumuskan masalah, memecahkan masalah dengan berbagai informasi yang didapat dan mencari solusi dengan benar sesuai informasi yang di dapat dan relevan.

Peserta didik harus menyadari akan pentingnya kemampuan berpikir kritis ini, melalui kemampuan ini siswa mampu menganalis suatu permasalahan yang ditemukan, mendapatkan informasi yang relevan dan nyata sehingga mendapatkan keputusan yang diyakini. Kebutuhan akan kemampuan berpikir kritis ini harus dikembangkan dan dilatih sejak bangku sekolah dasar, mengapa demikian siswa mampu menemukan jalan keluar dari kasus atau masalah yang ditemui dengan kemampuan tersebut. Pada pelaksanaan pembelajaran berpikir kritis berfokus pada penemuan konsep dari suatu masalah yang dihadapi. 
2523 Pengaruh Process Oriented Guided Inquiry Learning (POGIL) terhadap Kemampuan Berpikir Kritis Siswa di Sekolah Dasar - Setyani Wijaya, Sri Lestari Handayani

DOI: https://doi.org/10.31004/basicedu.v5i4.1227

Kenyataan yang dihadapi dalam dunia pendidikan sekarang, kemampuan berpikir kritis ini masih sangat minim diterapkan oleh Guru. Yang dimana seharusnya proses pembelajaran student center learning tetapi dalam pelaksanaanya berbanding terbalik (Amijaya 2018:98). Hasil wawancara di SD Angkasa 4 diperoleh data bahwa guru masih kurang melakukan kegiatan atau strategi yang melibatkan siswa untuk berikir kritis. Pelaksanaan proses belajar mengajar metode, model dan media yang digunakan tidak dapat menunjang untuk siswa mengembangkan kemampuan berpikir kritis. Kesenjangan yang muncul juga datang dari peserta didik. Terdapat dua faktor, faktor pertama yaitu faktor internal peserta didik mengalami kesulitan untuk menerima pembelajaran sehingga baik dalam aspek kognitif, afektif dan psikomotorik akan sedikit tertinggal dari teman lainnya.

Faktor kedua yaitu faktor eksternal, datang dari teman-temannya yang jahil atau mengajak ngobrol sehingga tidak fokus dalam proses pembelajaran. Kurangnya focus pada peserta didik juga menjadi masalah utama. Menurut Ennis (1996:169) mengungkapkan bahwa kemampuan berpikir kritis mempnyai enam tahap penting yaitu sering disebut dengan FRISCO. Jika salah satu tahap tersebut dilewatkan atau peserta didik kurang menguasai maka kemampuan berpikir kritis tidak terlaksana dengan baik dan akan menghambat kegiatan belajar mengajar.

Dalam pelaksanaan proses pembelajaran IPA tidak hanya cukup mendengarkan dan menghafal informasi yang disampaikan oleh Guru. Melalui berpikir kritis siswa belajar untuk melakukan proses penemuan. Diperlukannya variasi model, media, metode atau strategi dalam pelaksanan pembelajaran IPA agar siswa tidak pasif dalam pelaksanannya (Handayani et al., 2021:699). Variasi yang dapat dilakukan adalah dengan mengaplikasikan model pembelajaran (POGIL).

Inti pelaksaan proses belajar mengajar dengan melaksanakan model POGIL adalah peserta didik mampu mencari konsep secara mandiri. Melalui model POGIL siswa dapat melatih kemampuan berpikir kritis melalui aktif dalam berdisukusi kelompok, saling tukar pendapat dan ide serta dapat menjaga alasan pada saat berdiskusi sesuai konsep-konsep yang relevan. Dalam penerapan model POGIL, terdapat latihan-latihan yang menekankan siswa untuk dapat mencari konsep IPA secara mandiri terhadap materi pembelajaran (Barthlow, 2011:2).

Kelebihan yang akan didapat dengan menerapakan model POGIL yaitu: (1) proses pembelajaran menjadi lebih aktif karena diskusi bersama kelompok, (2) peserta didik secara mandiri menemukan konsep tentang materi yang diberikan, (3) merangsang kemampuan berpikir kritis peserta didik, (4) menimbulkan rasa percaya diri untuk memaparkan hasil diskusi bersama kelompok di depan kelas. Dibalik kelebihannya model POGIL mempunyai kekurangan yaitu: (1) memakan banyak waktu, (2) pembagian peran anggota dalam kelompok sulit dilakukan (Devi et al., 2019:80).

Banyak penelitian yang mengimplementasikan model POGIL sebagai salah satu variabelnya, hasil penelitian Devi (2019:86) membuktikan bahwa kelas yang mengaplikasikan model POGIL memberikan pengaruh yang baik. Keberhasilan lainnya juga dalam penelitian Ningsih (2012:52) kesimpulan dari penelitian tersebut model POGIL mampu memberikan dampak yang baik untuk kemampuan berpikir kritis siswa. Hal ini sependapat oleh Prathama (2017:9) hasil penelitian tersebut membuktikan adanya perbedaan hasil belajar IPA dengan mengaplikasikan model POGIL.

Dengan pelaksaan model POGIL pada proses belajar mengajar IPA mampu merangsang siswa untuk mencari konsep dari materi yang dipaparkan baik secara individu maupun berdiskusi dengan kelompok belajar dengan baik sehingga merangsang untuk berpikir kritis. Pencapaian terbesar yang diterima Guru adanya perubahan kognitif, afektif dan psikomotorik bagi siswa. Penelitian ini dilakukan untuk mengetahui apakah ada pengaruh positif dan signifikan model pembelajaran (POGIL) terhadap kemampuan berpikir kritis siswa kelas $\mathrm{V}$ materi kalor dan perpindahannya. 
2524 Pengaruh Process Oriented Guided Inquiry Learning (POGIL) terhadap Kemampuan Berpikir Kritis Siswa di Sekolah Dasar - Setyani Wijaya, Sri Lestari Handayani

DOI: https://doi.org/10.31004/basicedu.v5i4.1227

\section{METODE PENELITIAN}

Peneliti menggunakan (quasi eksperimen) yang dimana tidak melakukan kontrol terhadap semua variabel yang berpengaruh kepada variabel terikat. Dengan menggunakan control group pre-test post-test dengan menggunakan dua kelas. Kelas VA dengan mengaplikasikan metode konvensional dan kelas VB dengan mengaplikasikan model pembelajaran (POGIL).

Pelaksanan penelitian dilakukan di SD Angkasa 4 tahun ajar 2020/2021 pada semester genap. Penelitin menggunakan populasi seluruh peserta didik kelas $\mathrm{V}$ dipilih karena memenuhi karateristik yang berjumlah 81 siswa (Sugiyono, 2017:61). Kelas VA terdiri dari 27 siswa dan kelas VB terdiri dari 26 siswa. Data kedua kelas tersebut digunakan untuk menjadi sampel penelitian. Dalam penelitian pengambilan secara random sampling yaitu digunakan apabila anggota populasi bersifat homogen. Sampel diambil secara acak tanpa melihat tingakatan yang tercantum (Rostina, 2018:24).

Tabel 1. Rancangan Penelitian

\begin{tabular}{ccc}
\hline Kelas & Treatment & Post Test \\
\hline $\mathrm{B}$ & $\mathrm{X}_{\mathrm{E}}$ & $\mathrm{O}$ \\
\hline $\mathrm{A}$ & $\mathrm{X}_{\mathrm{K}}$ & $\mathrm{O}$ \\
\hline
\end{tabular}

Keterangan:

$\mathrm{B}=$ Kelas eksperimen

$\mathrm{A} \quad=$ Kelas kontrol

$\mathrm{X}_{\mathrm{E}} \quad=$ Penerapan model (POGIL)

$\mathrm{X}_{\mathrm{K}} \quad=$ Penerapan metode konvensional

$\mathrm{Y} \quad=$ Tes akhir berpikir kritis

Penelitian dilanjutkan dengan melakukan uji normalitas dan uji homogenitas sebelum melakukan uji analisis Instrument soal berjumlah 15 yang sudah dilakukan uji validitas. Instrumen soal ini berbentuk soal essay. Setelah melakukan uji prasyarat selanjutnya melakukan uji hipotesis uji-t Independent T-Test dengan bantuan SPSS versi 26.

\section{HASIL DAN PEMBAHASAN}

Dalam pembahasan akan menunjukkan data analisis statistic deskriptif sebelum dilakukan treatment (pre-test) dan sudah diberikan treatmen (post-test). Perolehan data hasil analisis statsitik deskriptif didapatkan hasil min, max, mean dan standar deviasi. Dibawah ini merupakan hasil analisis data statistic secara lebih jelas dapat dilihat di 2.

Tabel 2. Analisis Statistik Deskriptif

\begin{tabular}{|c|c|c|c|c|c|c|}
\hline \multirow{2}{*}{ Kelas } & Data & $\begin{array}{c}\text { Jumlah } \\
\text { Siswa }\end{array}$ & Min & Max & Mean & $\begin{array}{c}\text { Standar } \\
\text { Deviasi }\end{array}$ \\
\hline \multirow{2}{*}{ Eksperimen } & Pretest & 26 & 59 & 88 & 73,58 & 10,210 \\
\cline { 2 - 7 } & Posttest & 26 & 70 & 97 & 87,00 & 7,694 \\
\hline \multirow{2}{*}{ Kontrol } & Pretest & 27 & 55 & 89 & 72,63 & 11,540 \\
\cline { 2 - 7 } & Posttest & 27 & 65 & 91 & 81,44 & 7,480 \\
\hline
\end{tabular}

Berdasarkan pemaparan tabel 2, diperoleh informasi bahwa pada kelas eksperimen dengan mengaplikasikan model POGIL mean pre-test adalah 73,58. Min sebesar 59 dan max sebesar 88. Untuk standar deviasi sebesar 10,210. Untuk post-test nilai mean adalah 87, min sebesar 70 dan max sebesar 97. 
2525 Pengaruh Process Oriented Guided Inquiry Learning (POGIL) terhadap Kemampuan Berpikir Kritis Siswa di Sekolah Dasar - Setyani Wijaya, Sri Lestari Handayani

DOI: https://doi.org/10.31004/basicedu.v5i4.1227

Untuk standar deviasi sebesar 7,694. Sedangkan kelas kontrol dengan mengaplikasikan metode konvensional mean pre-test sebesar 72,63. Min sebesar 55 dan max sebesar 89. Untuk standar deviasi sebesar 11,540. Untuk post-test nilai mean adalah 81,44, min sebesar 65 dan nilai max sebesar 91 . Untuk standar deviasi sebesar 7,480. Dari data yang sudah dipaparkan bahwa terdapat selisih nilai sebelum dilakukan treatment dengan sesudah dilakukan treatment. Untuk kelas eksperimen adalah 13,42 sedangkan kelas kontrol adalah 8,81. Dari hasil peningkatan rata-rata kedua kelas membuktikan nilai tertinggi dipegang oleh kelas eksperimen.

Setelah melakukan analisis statistik deskriptif, selanjutnya melakukan uji prasyarat. Hasil uji normalitas dengan menggunakan uji Lilliefors akan dipaparkan melalui tabel dibawah ini. Pengujuian ini memberikan kesimpulan data yang dimiliki peneliti apakah berdistribusi normal atau tidak. Dibawah ini merupakan hasil uji normalitas secara lebih jelas dapat tertera di tabel 3.

Tabel 3. Uji Normalitas Lilliefors

\begin{tabular}{ccccc}
\hline \multirow{2}{*}{ Kelas } & \multirow{2}{*}{ Data } & \multicolumn{2}{c}{ Nilai } & \multirow{2}{*}{ Kesimpulan } \\
\cline { 3 - 4 } & & Sig. & Sig. $\boldsymbol{\alpha}$ & \\
\hline \multirow{2}{*}{ Eksperimen } & Pre-test & 0,052 & 0,05 & Normal \\
\cline { 2 - 4 } & Post-test & 0,116 & 0,05 & Normal \\
\hline \multirow{2}{*}{ Kontrol } & Pre-test & 0,054 & 0,05 & Normal \\
\cline { 2 - 4 } & Post-test & 0,060 & 0,05 & Normal \\
\hline
\end{tabular}

Ketentuan pengujian normalitas yaitu jika Sig. $>\alpha=5 \%$ maka data tersebut normal. Dari hasil pemaparan data diatas untuk kedua kelas mendistribusikan normal. Data yang telah diolah dengan bantuan SPSS versi 26 bahwa kedua kelas mengindikasikan hasil Sig. $>\alpha=5 \%$ maka data dari kedua kelas tersebut berdistribusi normal.

Uji hipotesis dengan menggunakan uji-t Independent T-Test untuk mengetahui apakah ada pengaruh positif dan signifikan model pembelajaran (POGIL) terhadap kemampuan berpikir kritis siswa kelas V SD Angkasa 4 pada materi kalor dan perpindahannya. Data yang digunakan adalah data post-test dari kedua kelas. Dibawah ini merupakan hasil uji-t secara lebih jelas dapat dilihat di tabel 4.

Tabel 4. Hasil Uji-t Independent T-Test

\begin{tabular}{cccc}
\hline \multirow{2}{*}{$\begin{array}{c}\text { Hasil } \\
\text { Berpikir } \\
\text { Kritis }\end{array}$} & $\begin{array}{c}\text { Sig. }(2- \\
\text { tailed })\end{array}$ & Sig. $\alpha$ & Kesimpulan \\
\cline { 2 - 4 } & 0,010 & 0,05 & $\begin{array}{c}\text { Terdapat } \\
\text { Pengaruh }\end{array}$ \\
\hline
\end{tabular}

Ketentuan pengujian uji-t dengan bantuan SPSS versi 26 for windows, yaitu jika nilai Asymp.(2-tailed) $<\alpha=5 \%$ disimpulkan bahwa data terdapat pengaruh terhadap dua variable (Rostina, 2018:98). Berdasarkan perhitungan uji-t Independent T-Test, didapatkan nilai Asymp.(2-tailed) sebesar 0,010 dengan demikian $\mathrm{H}_{\mathrm{o}}$ ditolak yaitu $0,010<0,05$ dan $\mathrm{H}_{1}$ diterima. Dari pemaparan data tersebut bahwa terdapat pengaruh terhadap dua variabel yang dilakukan pengujian.

Setelah melakukan analisis data maka didapatkan adanya temuan ini yaitu perbedaan antara kedua kelas pada hasil kemampuan berpikir kritis peserta didik dapat dilihat dari hasil uji-t .Selain itu, berdasarkan analisis deskriptif menunjukkan selisih mean sebelum diberikan treatment dan sesudah diberikan treatment untuk kedua kelas membuktikan nilai tertinggi dipegang oleh kelas eksperimen.

Perbedaan hasil berpikir kritis yang signifikan terjadi karena perbedaan tahapan-tahapan pembelajaran dan proses penyampaian materi. Pada kelas eksperimen mengaplikasikan model POGIL dan untuk kelas kontrol mengaplikasikan metode konvensional. Menurut Hanson (2006:5) model pembelajaran POGIL memilki 5 tahapan yaitu, tahap pertama orientasi (orientation), memaparkan tujuan pembelajaran sesuai RPP 
yaitu praktikum kalor dan perpindahannya baik secara konduksi, konveksi, dan radiasi. Sebelum melakukan praktikum peserta didik diberikan sebuah kasus yang relevan dengan kalor dan perpindahannya. Kasus yang diberikan untuk membangun kengintahuan peserta didik, dengan keingintahuan yang besar maka akan membangun rasa minat pada siswa. Kemudian, dengan menanamkan keinginan untuk belajar dan membandingkan pengetahuan saat ini dengan pengetahuan sebelumnya dengan mengajukan pertanyaan. Untuk dapat menjawab pertanyaan tersebut, peserta didik akan terlibat dalam pemikiran kritis sehingga dapat menjawab argumentasi yang matang dan relevan dengan konteks.

Tahap kedua eksplorasi (exploration), kegiatan yang dilakukan adalah melakukan diskusi secara kelompok yang terdiri 4 orang. Menurut Guleker \& Keci (2014:60) jika setiap anggota memiliki perannya masing-masing, mereka akan membangun dan memelihara pemahaman dan kemampuannya sendiri. Manager atau leader bertugas membagi tugas-tugas kepada anggota kelompok, dan memastikan bahwa setiap anggota ikut berpartisipasi. Perekam, bertugas untuk mencatat arahan dan hasil yang telah dilakukan oleh kelompok, serta menyiapkan laporan dari semuanya.

Analisis strategi, bertugas mengidentifikasi kelebihan dan kekurangan dalam kelompok serta pencapaian apa yang telah dilakukan dalam kelompok. Dan yang terakhir adalah juru bicara, bertugas mengkomunikasikan laporan dalam diskusi kelas. Tanggung jawab individu dan pembagian peran dalam kelompok dilakukan untuk meningkatkan kerja sama, saling bertukar pendapat.. Hal ini sejalan oleh Ningsih dkk (2012:51) tujuan peran yang dijalankan oleh masing-masing anggota untuk meningkatkan proses pembelajaran secara kooperatif (berkelompok), berpikir kritis, bertanggung jawab atas perannya masingmasing, saling tukar pendapat, menarik kesimpulan, dan memecahkan masalah. Guru memberikan tugas dalam bentuk lembar aktivitas pembelajaran (LAP) untuk mengetahui sejauh mana siswa memahami praktikum kalor dan perpindahanya yang tertuju untuk mencapai tujuan pembelajaran. Pemberian LAP ini dapat mengembangkan berpikir kritis siswa menemukan konsep secara individu melalui kegiatan praktikum kalor dan perpindahannya, dengan penemuan konsep maka peserta didik dapat menjawab berbagai pertanyaan pada LAP, dan memecahkan masalah secara kelompok.

Menurut Ennis (1996:169) menyatakan bahwa terdapat lima aspek indikator dalam kemampuan berpikir kritiis yaitu, (1) peserta didik dapat merumuskan pertanyaan yang ada pada LAP, menganalisa argument, dan bertanya dan menjawab pertanyaan sehingga mampu memaparkan secara singkat, padat, dan jelas. (2) melakukan observasi, yang di dalamnya mempertimbangkan sumber-sumber untuk penguatan dalam memberikan argument, setelah itu dapat membuat kesimpulan secara sederhana. (3) membuat kesimpulan dengan hasil sumber-sumber yang telah ditemukan. (4) mencari arti dari istilah-istilah yang dipakai, membuat asumsi yang dibutuhkan dan untuk mendukung argument dan (5) membuat strategi untuk memutuskan suatu tindakan. Dalam proses pembelajaran siswa menerapkan keterampilan dasar dengan melakukan praktikum serta mendapatkan hasil dari praktikum kalor dan perpindahannya. Peserta didik melakukan praktikum kalor perpindahan secara konduksi, konveksi, dan radiasi. Setelah mendapatkan data kemudian siswa dapat memberikan kesimpulan dari praktikum yang telah dilaksanakan. Setalah itu juru bicara setiap kelompok mendapatkan kesempatan untuk memaparkan hasil diskusi bersama di depan kelas.

Tahap ketiga pembentukan konsep (concept formation), Guru sebagai fasilitator melibatkan siswa dalam menemukan konsep secara inkuiri terbimbing dengan siswa. Dalam menemukan konsep secara inkuiri terbimbing dengan siswa, mereka dapat menemukan konsep secara mandiri. Maka peserta didik berhasil menjawab berbagai pertanyaan ditunjukkan untuk memahami konseptual mereka. Pengaplikasikan indikator pada tahap ini adalah merumuskan pertanyaan yang ada pada LAP, menganalisa argumen, dan bertanya dan menjawab pertanyaan sehingga mampu memaparkan secara singkat, padat, dan jelas. Siswa dapat menjawab pertanyaan-pertanyaan yang mampu mengembangkan pemahaman suatu konsep. Pada tahap ini guru memancing siswa untuk berpikir kritis untuk dapat menjawab secara baik pertanyaan yang diberikan. Setiap kelompok dihadapkan bagaimana dapat memutuskan suatu tindakan yang ditemukan pada saat menjawab 
2527 Pengaruh Process Oriented Guided Inquiry Learning (POGIL) terhadap Kemampuan Berpikir Kritis Siswa di Sekolah Dasar - Setyani Wijaya , Sri Lestari Handayani

DOI: https://doi.org/10.31004/basicedu.v5i4.1227

berbagai pertanyaan pada LAP. Sehingga dapat mengambil keputusan yang tepat sesuai untuk memecahkan masalah secara kelompok pada soal LAP. Pada kegiatan ini siswa menerapkan staretegi dan taktik dengan baik.

Tahap keempat aplikasi (application), pengetahuan yang baru didapatkan dari penemuan konsep kemudian diaplikasikan dalam memecahkan masalah. Pengaplikasikan indikator pada tahap ini adalah memutuskan suatu tindakan bersama kelompok. Pemaparan ini sesuai dengan penelitian oleh Brown (2010:4) mengungkapkan dengan memecahakan masalah bersama dapat melatih kemampuan berpikir kritis. Dan tahap kelima penutup (closer), Peserta didik dan Guru memvalidasi hasil diskusi bersama kelompok serta menilai kinerjanya. Indikator kemampuan berpikir kritis yang diterapkan adalah membuat kesimpulan, peserta didik memberikan kesimpulan yang didapat setelah melakukan pembelajaran kemudian Guru akan menambahkan penguatan kesimpulan yang telah dipaparkan oleh siswa. Melalui kegiatan refleksi Guru mengetahui kemampuan yang didapat setelah melakukan pembelaajaran untuk dapat meningkatkan kemampuannya pada pertemuan lainnya.

Dalam fakta yang ditemukan di lapangan peserta didik dan guru memiliki perannya masing-maising untuk dilaksanakan agar tujuan pembelajaran yang ditetapkan dapat terwujud. Guru sebagai pemimpin berperan untuk merencanakan pembelajaran yang berorientasi kepada tujuan pembelajaran. Guru mengatur jalannya proses pembelajaran dan mengetahui pencapaian siswa dalam berpikir kritis sebagai monitoring. Guru sebagai fasilitator akan mengatasi kekurangan yang ada pada peserta didik atau mengembangkan kemampuan berpikir kritis. Kegiatan yang dilakukan dengan membangkitkan konflik kognitif pada peserta didik, seperti melalui pertanyaan, memberikan analogi atau kegiatan lainnya yang dapat menimbulkan siswa untuk berpikir kritis. Guru sebagai evaluator melakukan evaluasi dari setiap pertemuan bagaimana kemampuan yang dimiliki peserta didik akan mengalami peningkatan atau penurunan (Barthlow, 2011).

Selama penelitian berlangsung Guru melakukan pengamatan terhadap kedua kelas. Untuk kelas eksperimen siswa menunjukkan sangat aktif dalam berdiskusi secara kelompok. Selama proses belajar mengajar peserta didik memiliki keingintahuan yang tinggi sehingga menyebabkan siswa mampu memecahkan masalah yang terjadi pada kehidupannya dengan model POGIL, dan siswa mencari bagaimana cara masalah ini dapat terpecahkan yang dilakukan secara kelompok dan siswa dapat memberikan kesimpulan dari masalah yang diberikan. Masalah ini berupa praktikum yang dilakukan di rumah, dengan memaparkan hasil dari praktikum tersebut kepada peneliti sebagai bukti siswa dapat mempraktekkan dan menyimpulkan pembelajaran.

Perbedaan yang dapat dilihat dari pembelajaran pada kedua kelas yaitu suasana kelas. Pada kelas yang mengaplikasikan model POGIL peserta didik bekerja sama secara kelompok cenderung siswa ikut aktifi dalam diskusi di dalam kelas sehingga pembelajaran akan menjadi menarik dan tidak membosankan dan menimbulkan rasa persaingan yang sehat antar kelompok satu dengan yang lainnya. Sedangkan metode konvensional, suasana kelas cenderung pasif karena guru tidak memberikan perlakuan. Pelaksanaanya guru lebih mendominasi daripada peserta didik, sehingga komunikasi dua arah pada proses pembelajaran tidak terlaksana menyebabkan pembelajaran menjadi pasif. Penyampaian materi biasa dilakukan melalui ceramah, tanya jawab, penugasan memberikan soal instrumen. Pembelajaran ini membuat siswa bosan, siswa cenderung menunggu informasi dari guru, dan hanya menghafal konsep saja.

Temuan ini juga diperkuat dengan hasil penelitian Rahayu dan Pamelasari (2015:943) bahwa terdapat pengaruh yang lebih besar terhadap kemampuan berpikir kritis untuk kelas yang mengaplikasikan model POGIL Pernyataan ini sejalan dengan penelitian oleh Lestari (2016:8) membuktikan terdapat pengaruh hasil belajar dan minat belajar dengan menerapkan model POGI. Dari hasil analisis diatas dapat dibuktikan bahwa model pembelajaran (POGIL) dapat memberikan pengaruh positif dan signifikan terhadap kemampuan berpikir kritis. Dalam pelaksanaanya masih belum optimal mencapai kemampuan berpikir kritis dengan sangat baik karena terjadi beberarapa hambatan yaitu, (1) Peserta didik belum memahami dan terbiasa dengan model 
2528 Pengaruh Process Oriented Guided Inquiry Learning (POGIL) terhadap Kemampuan Berpikir Kritis Siswa di Sekolah Dasar - Setyani Wijaya, Sri Lestari Handayani

DOI: https://doi.org/10.31004/basicedu.v5i4.1227

POGIL. (2) Membutuhkan waktu lama untuk membiasakan penerapan model POGIL. (3) Peserta didik belum terbiasa berdiskusi secara kelompok sehingga dalam menyelesaikan LAP membutuhkan menejemen waktu yang cukup lama.

Implikasi temuan dari penelitian ini adalah mengaplikasikan model (POGIL) dapat memberikan pengaruh positif dan signifikan terhadap kemampuan berpikir kritis. Deduksi ini dapat dibuktikan melalui hasil uji-t yang menunjukan nilai sebesar Asymp.(2-tailed) lebih kecil daripada taraf signifikansi yaitu 5\%. Hal ini dapat terjadi disebabkan model pembelajaran (POGIL) memotivasi peserta didik dapat aktif dalam berdiskusi secara kelompok dengan kegiatan inkuiri terbimbing, sehingga memungkinkan siswa untuk lebih memahami fakta dan konsep. Aktifnya peserta didik dalam proses pembelajaran akan menimbulkan rasa tidak bosan, kemudian siswa memiliki jiwa kompetisi yang besar lewat kemampuan menemukan konsep secara mandiri dan berkelompok dalam praktikum. Guru juga memiliki peran sebagai pemimpin, fasilitator, monitor, dan evaluator. Selain itu, menjawab dan memecahkan soal pada LAP peserta didik mampu berpikir kritis dengan baik melalui pendapat atau pertanyaan yang dipaparkan dalam berdiskusi. Peserta didik berhasil menemukan materi yang diberikan sehingga dapat menemukan konsep secara mandiri sehingga peserta didik memiliki daya ingat yang kuat terutama untuk materi yang diberikan.

Dengan berakhirya penelitian ini membawa dampak pengaruh positif dan signifikan terhadap berpikir kritis siswa menjadi maksimal dengan menggunakan model (POGIL) diharapkan Guru mampu menerapkan model ini agar peserta lebih aktif saat proses belajar mengajar berlangsung secara diskusi kelompok mampu menemukan keputusan untuk kasus yang dihadapi.

\section{KESIMPULAN}

Peneliti membuat kesimpulan didasarkan pada pemaparan di atas, dapat ditarik kesimpulan terdapat pengaruh positif dan signifikan model pembelajaran Process Oriented Guided Inquiry Learning (POGIL) terhadap kemampuan berpikir kritis peserta didik kelas V SD Angkasa 4 materi kalor dan perpindahannya. Dapat dibuktikan dengan pengujian uji-t menunjukkan bahwa Asymp.(2-tailed) sebesar 0,010. Oleh karena jika nilai Asymp.(2-tailed) lebih kecil daripada $\alpha=5 \%$ maka $\mathrm{H}_{\mathrm{o}}$ ditolak dan $\mathrm{H}_{1}$ diterima.

Melalui penelitian ditemukan beberapa saran yaitu: (1) siswa hendaknya meningkatkan keaktifan dalam kegiatan belajar kelompok dan antusiasme pada pengetahuan baru. (2) Guru dapat memperbaiki dan meningkatkan kinerja dengan memilih model pembelajaran yang bervariasi dan inovatif. Guru juga dapat melakukan kegiatan atau stretegi untuk dapat mengembangkan kemampuan berpikir kritis siswa. Dalam pelaksanaan pembelajaran Guru dapat mengaplikasikan model POGIL. (3) untuk peneliti berikutnya, dapat menggunakan penelitian ini sebagai acuan, kemudian memperbanyak variabel sehingga mampu menyempurnakan penelitian yang serupa.

\section{DAFTAR PUSTAKA}

Amijaya Lalu Sunarya, Agus Ramdani, I. W. M. (2018). Pengaruh Model Pembelajaran Inkuiri Terbimbing Terhadap Hasil Belajar Dan Kemampuan Berpikir Kritis Peserta Didik. 13(2), 38-87.

Barthlow, M. J. (2011). The Effectiveness Of Process Oriented Guided Inquiry Learning. 319.

Brown, S. D. (2010). A Process-Oriented Guided Inquiry Approach To Teaching Medicinal Chemistry. American Journal Of Pharmaceutical Education, 74(7), 1-6. Https://Doi.Org/10.5688/Aj7407121

Cross, K. P., \& Angelo, T. A. (1988). Classroom Assessment Techniques: A Handbook For Faculty. The National Center For Research To Improve Post-Secondary Teaching And Learning.

Devi, E. K., Sulistri, E., \& Rosdianto, H. (2019). Pengaruh Model Pembelajaran Process Oriented Guided 
2529 Pengaruh Process Oriented Guided Inquiry Learning (POGIL) terhadap Kemampuan Berpikir Kritis Siswa di Sekolah Dasar - Setyani Wijaya, Sri Lestari Handayani

DOI: https://doi.org/10.31004/basicedu.v5i4.1227

Inquiry Learning (Pogil) Terhadap Kemampuan Berpikir Kritis Siswa Pada Materi Hukum Archimedes. Konstan - Jurnal Fisika Dan Pendidikan Fisika, 4(2), $78-88$. Https://Doi.Org/10.20414/Konstan.V4i2.42

Ennis, R. H. (1996). Critical Thinking Dispositions: Their Nature And Assessability. Informal Logic, 18(2), 165-182. Https://Doi.Org/10.22329/Il.V18i2.2378

Facione, P. A. (2011). Critical Thinking: What It Is And Why It Counts. Insight Assessment, Isbn 13: 978-1891557-07-1., 1-28. Https://Www.Insightassessment.Com/Ct-Resources/Teaching-For-And-AboutCritical-Thinking/Critical-Thinking-What-It-Is-And-Why-It-Counts/Critical-Thinking-What-It-Is-AndWhy-It-Counts-Pdf

Guleker, R., \& Keci, J. (2014). The Effect Of Attendance On Academic Performance. Mediterranean Journal Of Social Sciences, 5(23), 961-966. Https://Doi.Org/10.5901/Mjss.2014.V5n23p961

Handayani, S. L., Budiarti, I. G., Kusmajid, K., \& Khairil, K. (2021). Problem Based Instruction Berbantuan E-Learning: Pengaruhnya Terhadap Kemampuan Berpikir Kritis Peserta Didik Sekolah Dasar. Jurnal Basicedu, 5(2), 697-705. Https://Doi.Org/10.31004/Basicedu.V5i2.795

Hanson, D. M., Bunce, D., Creegan, F., Moog, R., Padwa, L., Spencer, J., Straumanis, A., Wolfskill, T., \& Hanson, D. M. (2006). Instructor' $S$ Guide To Process Oriented Guided Inquiry Learning By With Contributions From Other Pogil Project Personnel: Instructor' S Guide To Process Oriented Guided Inquiry Learning. 56.

Kowiyah. (2012). Kemampuan Berpikir Kritis. Jurnal Pendidikan Dasar, 3(5), 175-179.

Lestari Desak Putu Sri, Made Sulastri, I. G. M. (2016). Pengaruh Model Pogil Dan Gaya Kognitif Terhadap Hasil Belajar Ipa Pada Siswa Kelas V Sd. Jurnal Pendidikan Dan Pengajaran, 49(2), 70. Https://Doi.Org/10.23887/Jppundiksha.V49i2.9011

Ningsih, S. M., \& Bambang, S. (2012). Implementasi Model Pembelajaran Process Oriented Guided Inquiry Learning (Pogil) Untuk Meningkatkan Kemampuan Berpikir Kritis Siswa. Upej (Unnes Physics Education Journal), 1(2). Https://Doi.Org/10.15294/Upej.V1i2.1364

Pendidikan, K. (2016). Implementasi Kurikulum 2013 Sd Mi. Jurnal Inovasi Pendidikan, 1(3).

Possin, K. (2017). Thinking Critically About Richard Paul' S Critical Thinking. Association For Informal Logic And Critical Thinking, 1(1), 1-10.

Prathama, I. W. G. O., Margunayasa, I. G., \& Wibawa, I. M. C. (2017). Pengaruh Model Pembelajaran Pogil Terhadap Hasil Belajar Ipa Pada Siswa Kelas V Sd. 52.

Rahayu Dita Puji, P. S. D. (2015). Pengaruh Model Pembelajaran Process Oriented Guided Inquiry Learning Terhadap Kemampuan Berpikir Kritispeserta Didik Pada Materi Perubahan Benda. Usej - Unnes Science Education Journal, 4(3). Https://Doi.Org/10.15294/Usej.V4i3.8836

Rostina, S. (2018). Statistika Penelitian Pendidikan. Alfabeta.

Sugiyono. (2017). Statistika Untuk Penelitian (P. 390). Alfabeta.

Sulistyowarni, P. A. D., Prahani, B. K., Supardi, Z. A. I., \& Jatmiko, B. (2019). The Effectiveness Of Or-Ipa Teaching Model To Improve Students' Critical Thinking Skills On Senior High School Physics Subject. Journal Of Physics: Conference Series, 1157(3). Https://Doi.Org/10.1088/1742-6596/1157/3/032011

Yasushi, G. (2011). Development Of Critical Thinking Rubric. 13 International Conference On Cognition And Exploratory Learning In Digital Age ( Celda 2016), Celda, 2010-2012. 